\title{
THE FORMATION OF A SYSTEM OF OPEN GOVERNMENT IN RUSSIA: EXPERIENCE AND PROSPECTS*
}

\section{Dmitrieva Natalia E.}

Ph.D. in Sociology; senior researcher at the Institute of Public Administration, HSE. Address: Higher School of Economics National Research University. 20 Myasnitskaya St., Moscow 101000, Russian Federation. E-mail: nedmitrieva@hse.ru.

\section{Styrin Evgeny M.}

Ph.D. in Sociology; senior researcher at the Institute of Public Administration, HSE. Address: Higher School of Economics National Research University. 20 Myasnitskaya St., Moscow 101000, Russian Federation.

E-mail: estyrin@gmail.com.

\begin{abstract}
This paper analyzes the development of forms and methods of interaction between government agencies and the experts' community, public organizations, and citizens under the influence of a whole host of factors, including a transition to networked forms of administration; the production and exchange of big data; the dynamic development of information and communication technologies; and the development of the need for various interest groups, members of the mass media, and citizens to comment and influence government decisionmaking. The goal of the paper is to demonstrate that open government and increasing citizen activity is a two-way street. The paper uses the results of the monitoring by experts in 2014 of the implementation of principles and mechanisms of openness in federal executive agencies.

One of the paper's tasks is to show that government bodies today face the extremely difficult challenge of not merely informing citizens about decisions that are made but also maintaining the smooth operation of mechanisms that are able, given the current level of social development, to ensure that the interests and expectations of as many stakeholders as possible are taken into account. The paper also analyzes issues related to streamlining the current mechanisms of openness.

The authors regard these technologies and mechanisms of openness and public participation in government administration as interconnected elements of a new, nascent model of public administration.
\end{abstract}

Keywords: open government; open data; civic councils; openness rating; mechanisms and principles of openness; presence in social networks; interest groups; system of open government; experts' monitoring.

* Translated by Steven Shabad 


\section{Introduction}

The formation of a system of open government in Russia is a natural phase in the improvement of public administration.

The previous period involved the implementation of an administrative reform in the Russian Federation, the reform of the civil-service system and the introduction of e-government technologies. The key objectives of the reforms of the 2000s were defined as ensuring that government information resources are open and accessible to citizens and organizations, increasing the transparency of government activities at all levels and streamlining the interaction between the civil service and civil-society institutions.

However, the absence in the process of bureaucratic self-reformation of tools for independent control of the quality and effectiveness of results, and the limited stake of bureaucrats in developing and advancing into the public arena successful practices for involving civil-society entities in framing tasks for government and determining paths of socio-economic development, have made it necessary to undertake new efforts and comprehensive measures to further improve the system of public administration.

Russian society today needs real evidence that government bodies are ready not only for nominal support for the decisions they adopt but also for partnership, for looking for compromises with a minority and for building a constructive nationwide dialogue.

Open and transparent government is one such guarantee.

Based on the above, the authors have formulated the principal hypothesis of their study as a working definition of a system of open government. It is a system of institutions (including principles, legislative statutes, and the organization of activities) that are created for the interaction of public government bodies with citizens and civil-society entities, as well as technologies that provide for feedback and mechanisms (tools) aimed at citizen involvement and participation in the drafting, adoption, implementation, and public monitoring of government's administrative decisions.

The performance and productivity of a system of open government can be evaluated only in an integrated fashion: by evaluating both the performance of its individual elements and the openness and transparency of the exercise by government bodies of their powers and functions.

In order to support their hypotheses, the authors will first define the goals, tasks, and major elements of the system of open government. Then they will describe the experts' monitoring methodology and, using the example of selected mechanisms for applying the principles of openness, reveal the key areas for implementing the system of open government and evaluate the stages of its formation. Finally, some overarching conclusions will be drawn about the prospects for further development of the system of open government.

\section{Prerequisites for the formation of open government}

Theorists and practitioners continue today to search for new concepts and models that allow technological achievements to be adapted most effectively to 
organizing systems of public administration. The most important international studies are the doctrine of "lean government" formulated by Janssen \& Estevez (2013) and the model of "networked government" proposed by Goldsmith \& Eggers (2004).

The doctrine of "networked government" provides for concentrating the efforts of government managers not on administering resources and processes but on changing the problem-solving principle - by creating a network of involved partners, namely nonprofit organizations, businesses, experts, and citizens with initiative. Responsibility for the end result, however, remains with government.

The "lean government" doctrine implements the ideas of "networked government" on the basis of e-government technologies. While simplifying internal administrative processes and incentivizing innovative approaches to problemsolving, government bodies introduce crowd-sourcing and wiki and mobile technologies that are designed not only to obtain more quickly information on society's problems and needs, but also to adopt decisions online while factoring in the views of all stakeholders. The "lean government" doctrine calls for the creation of platform-based solutions that allow both government and nongovernmental services to be set up on a common platform, according to common standards. The technological platform practices the principle of competition, whereby any supplier of services will be able, provided that it meets the prescribed requirements and standards of platform compatibility, to develop and sell services on it.

By developing "platform-based governance," a government will be able to flexibly formulate and change priorities, incentivizing developers and meeting the interests of citizens as the end users of services. In addition, commercial services will ensure an influx of users and indirectly promote government services, thereby speeding the process of repayment of government investments in the creation of e-government. Finally, government services on a common platform will be able to compete with commercial ones, which in the medium term will enhance their quality and availability.

The term "public sector information" (PSI) is used today to define government information. Burkert (2004) notes the substantial change in government's role in the provision and use of PSI under the pressure of increased demand from civil society. While initially society assigns to government the functions of gathering, storing, and providing socially important information, at the following stage, as an OECD report noted, market competition will lead to the emergence of new, advanced products on the basis of open government information (Organisation for Economic Co-operation and Development, 2006). Finally, Stiglitz (2000) regards government's role as that of a facilitator that accelerates the processes of market growth and corporate development, services, and ideas on the basis of usage, including government information that is disclosed.

An equally important factor in the search for an efficient model of government is the initiatives of leading world politicians and leaders. Above all, this means the initiatives of the international community of 64 counties that belong to the Open Government Partnership and formulate an international agenda.

Thus, the incomplete status of the previous stages of reform of the system of government, and the dissatisfaction of government and the public with the lack of 
obvious achievements on the one hand and the evolving worldwide trends on the other, were the source for the doctrine of open government in Russia.

\section{Sources of the open-government doctrine in Russia}

One of the most important achievements in this area was the adoption in 2009 of the Federal Law "On Providing Access to Information on the Activities of National and Local Government Bodies" and a whole host of statutory instruments. The significant progress in this regard is confirmed by the international Right to Information (RTI) Rating, which evaluates, according to 61 parameters in 102 countries, the quality of national legislation on access to information (http://new.rti-rating.org/country-data ). Based on data from year 2009, Russia ranked overall $31^{\text {st }}$ (a score of 98 out of 150), in the middle part of the ranking. We should note that the websites of all national government bodies in the Russian Federation have now been unified on a common server, "Official Russia" (http://www.gov.ru), which greatly simplifies access to them.

This also resulted in the creation on the Internet of a whole host of government information portals and systems that disclose information on the activities of national government bodies and enable them to interact with citizens. They include the Unified Portal of National and Municipal Government Services (Functions) (www.gosuslugi.ru); an information system that monitors the quality of national and municipal services (https://vashkontrol.ru); an official website that posts orders for goods, work, and services (zakupki.gov.ru); a common portal that posts information on the formulation by federal executive agencies of drafts for regulatory and legal statutes and the results of their public discussion (http://regulation.gov.ru/index.html); and many others.

The significant results also include the formation of a representative community of experts on public administration: more than 1,000 independent experts were recruited as part of the activities of the working groups established under the Government Commission on Administrative Reform. Another consequence has been a surge of theoretical papers and research projects and the emergence of a large number of research centers and public organizations that deal with issues related to the improvement of public administration in Russia.

Russian President Vladimir V. Putin explicitly stated in his annual Message to the Federal Assembly of the Russian Federation on December 12, 2013, that Russia today must have a broad public debate, and one with practical results, where public initiatives become part of government policy and society monitors their implementation.

Despite the fact that current Russian law already contains a whole host of provisions that allow government bodies to construct a system of interactions with the public, its primary vector is based on government dominance in the regulation of relations with the institutions of civil society. For example, the memberships of civic councils are approved by orders from agency heads; independent experts are invited as consultants and sources of additional information during the discussion of decisions prepared by government bodies; and nonprofit organizations are recruited primarily as participants in the implementation of government programs. 


\section{What is a system of "open government"?}

The traditional forms of organizing interaction between government bodies and the public, under which they act within their authority and issue information to society at their discretion, piecemeal, not only impede an efficient exchange of information but also engender passivity among Russians, distrust toward government institutions, and a reluctance to participate in the political and socioeconomic transformations under way in the country.

Access to information on the activities of agencies that provides sufficient and accurate facts on the results of their work and on government's intentions expands opportunities for public participation in governance and enables citizens, public associations, and the business community to make better-informed decisions based on objective information.

Therefore, if the institutions of civil society are to participate more actively in forming an open information society, and if intersectoral partnership is to develop among government bodies, business, and the public, there must be qualitative changes in the way the activities of the executive branch are organized, based on the principles of open public governance. In this sense open government is the technology of institutionalizing the interaction among government, business, and society. This is the principal purpose of the system of open government that is to be created.

Another, no less important goal is the adaptation of the institutions of public governance to the challenges of forming a market economy.

It is a universally accepted view that effective socio-economic development requires that legal and political institutions are aligned with economic institutions. Today it is becoming increasingly obvious that the development of a market economy in Russia, among other things, is hamstrung by the enormous legacy of the administrative-command system of governance. The doctrine of "new public management," which propounds the use of the private sector's managerial techniques in the public sector, has been adopted only in certain areas of public governance.

The dominant role chosen by the government at the current stage in establishing platforms and channels for interaction with civil society must change. Government institutions, of course, retain all of the key resources and levers. But the vector of development today must be changed: materials, equipment, and information resources must be transferred to civil-society institutions, providing an incentive for them to organize themselves and to instill in every citizen entrepreneurial activism and responsibility for themselves and their future, rather than a passive expectation of assistance from the government. Civil society must strive to take on responsibility for the regulation of public interests, while government bodies must develop a need in ordinary citizens to participate in public governance. Such processes will make it possible to escape the administrative-command style in public governance.

Certain positive examples are already appearing in Russian practice; for example, the establishment of annual ratings of the openness of information on the activities of national and local government bodies at official websites. These rat- 
ings are conducted today both by using the government automated information system "Government Website Ratings" (http://gosmonitor.ru) and by the Institute for the Development of Freedom of Information, a nonprofit organization (http://svobodainfo.org/ru) going back to 2005 .

It is important to note that government bodies take the results of both ratings into account. For example, in competing with each other, the government and private ratings promote an improvement of the official websites of national and local government bodies. The application of the "networked government" model, in our view, will make it possible to turn a few examples into a widespread practice.

And finally, the introduction of a system of open government should ensure the creation of a qualitatively new level of representation of public interests and the aggregation of the needs of various civil-society entities.

We share S.S. Smoleva's position that social development in an open society should be planned not by the representatives of government but by all individuals who take a critical view both of their own activities and of government's steps. We also support the conclusions of T.A. Modasova regarding the key role of public participation, the purpose of which is to articulate public interests and, and by achieving the mutual alignment of interests among various social groups, to determine the sequence and priority in dealing with various issues (Mordasova, 2011, Smoleva, 2008).

We will now look at the key elements of the system of open government in more detail.

First are the formalized provisions of the law. As of the time when the projects to increase the openness and transparency of the activities of public government bodies were launched, more than 40 federal regulatory and legal statutes containing provisions in this area had already been adopted. A regulatory and legal framework for the establishment of a system of open government is already undergoing intensive development. Above all, this includes the Federal Laws adopted in 2014 "On the Principles of Public Monitoring in the Russian Federation" and "On Citizen Participation in the Maintenance of Public Order" and a Federal Law that deals with issues related to providing independent ratings of the quality of services rendered by entities in the realms of culture, social services, health care, and education.

An important role in forming the system is played by the adoption of the Openness Standards for Federal Executive Agencies, as part of the work of the Government Commission to Coordinate the Activities of an Open Government, with the active participation of members of the Experts' Council under the Russian Federation Government, the Civic Chamber of the Russian Federation. and the Council under the Russian Federation President for the Development of a Civil Society and Human Rights, and in dialog with the civil servants of executive bodies (hereinafter, the Openness Standards).

The Openness Standards constitute a comprehensive document that consists of a Framework of Openness of Federal executive agencies, approved by the Russian Federation Government; Guidelines for Implementing the Principles of Openness in Federal Executive Agencies; and a Procedure for Rating and Evalu- 
ating the Openness of Federal Executive Agencies, approved by the Government Commission to Coordinate the Activities of an Open Government (Standart otkrytosti federalnykh organov ispolnitel'noi vlasti).

Second are the basic principles of openness, which are defined in the Openness Standards as the guiding values for establishing a system of open government:

- the principle of openness of information;

- the principle of clarity regarding the goals, tasks, plans, and results of the activities of executive bodies;

- the principle of civil-society involvement in the formulation and implementation of governmental decisions;

- the principle of public monitoring and the accountability of government bodies.

The third major element of the system of open government is the formation of a far-flung system of administrative institutions. Primarily these are formal and informal procedures of interaction with the following administrative entities:

- consultative and advisory bodies, attached to the President and the Government of Russia; to federal executive agencies; to the government bodies of constituent entities of the Russian Federation; and to local government bodies;

- the Civic Chamber of the Russian Federation and civic chambers in the constituent entities of the Russian Federation;

- human-rights representatives and representatives for the protection of entrepreneurs' rights at the federal and regional levels;

- professional, youth, and public associations, nonprofit organizations, etc.

As of October 1, 2014, there were more than 100 consultative and coordinating bodies attached to the President and the Government of the Russian Federation; of these, 72 were government commissions, and there were 18 President's Councils and 13 Presidential Commissions (President's Councils; Russian Government Coordination and Consultation Boards). Consultative bodies are also being established and attached to other government bodies, such as the Prosecutor General's Office, the Supreme Court, and others, and to the government bodies of constituent entities of the Russian Federation.

In addition, administrative institutions include mechanisms and instruments whose development helps to create a new system of relations between government bodies and civil-society entities. They consist, above all, of a public declaration, plan and public reports by an agency; independent experts' anticorruption reviews of draft statutes that are being prepared; a presence in social networks, etc.

The fourth element of the system of open government is the institutionalization of ICT (information and communication technologies) (Fountain, 2001). ICT technologies are being introduced into key administrative processes in all government bodies: the provision of government services in electronic format (e-government); the discussion of drafts by agencies and citizen initiatives (e-participation, e-rulemaking); access to information by means of websites, mail-outs, social media, and so forth. We believe that ICT are the most conducive means to the development of mechanisms of openness. 


\section{Key areas for implementation of a system of open government}

\section{Experts' monitoring methodology}

In order to test the hypothesis of open government as a system, the authors developed a methodology for monitoring by experts, with due regard for the provisions of the Procedure for Rating and Evaluating the Openness of Federal executive agencies, approved by the Government Commission to Coordinate the Activities of an Open Government, on the basis of the approved performance criteria:

- the orientation of the openness mechanism toward the end user (including interest groups, citizens, public associations, etc.);

- the degree of involvement of the experts' community and public associations in the work of the openness mechanism and the demand for it;

- the transparency of the openness mechanism's operation.

As part of this paper, the results of the study will be presented in the case of four openness mechanisms: civic councils, interest groups, open data, and social networks. The reason they were chosen was that they make it possible to test the level of implementation at federal agencies of three different principles of the system of open government:

- $\quad$ openness of information (in the case of working with open data);

- public monitoring (in the case of civic councils);

- civil-society involvement in the formulation and implementation of governmental decisions (in the case of interest groups and social networks).

The experts' monitoring employed questionnaires, a survey of experts, and an analysis of official websites. The questionnaires for experts, prepared for each of the openness mechanisms, included up to seven or eight parameters, grouped according to three criteria: the accessibility, clarity, and utility of the mechanism for citizens. The reason for choosing these criteria was not so much the need to verify the results of the previous self-survey conducted by federal executive agencies regarding the implementation of openness mechanisms, as the importance of an evaluation by experts of the level of development of each mechanism.

The questionnaires were filled out using a point scale to rate each of 78 federal executive agencies in two stages: first, junior experts (who consisted of students in the social sciences division of the Higher School of Economics) did a formal evaluation according to each parameter; then, senior experts (researchers at the Institute of Public Administration and Municipal Management of the Higher School of Economics) conducted a qualitative evaluation according to all the parameters selected to evaluate the mechanism, with the ability to selectively double-check and correct the quantitative evaluations.

Then the identified trends of development of the openness mechanisms were applied to the theoretical models: those of civic councils were applied to Freeman's stakeholder theory (Freeman, 1984) and Tullock's externalities theory (Tallok, 2011), while those of social networks were applied to Mergel's model (2013). The open data were evaluated by experts; since their development was just beginning, no evaluation of the economic benefit of open data was conducted. 


\section{Some results of restarting the civic councils}

As of October 1,2014, civic councils had been set up for 58 federal executive bodies, and a total of about 2,200 people had been recruited to serve on them. An analysis of the overall makeup of the civic councils attached to federal executive agencies (FEAs) identified the following specific features of the approved memberships of these councils:

- more than 70 percent of the members of civic councils are the heads or deputy heads of the entities that they represent:

- every tenth participant belongs to two or more civic councils;

- $\quad$ about 8 percent are simultaneously members of the updated Experts' Council attached to the Russian Federation Government (Sostav, 2012).

Figure

\section{Distribution of interest-group representation} in the approved memberships of civic councils attached to federal executive agencies (FEAs), \%

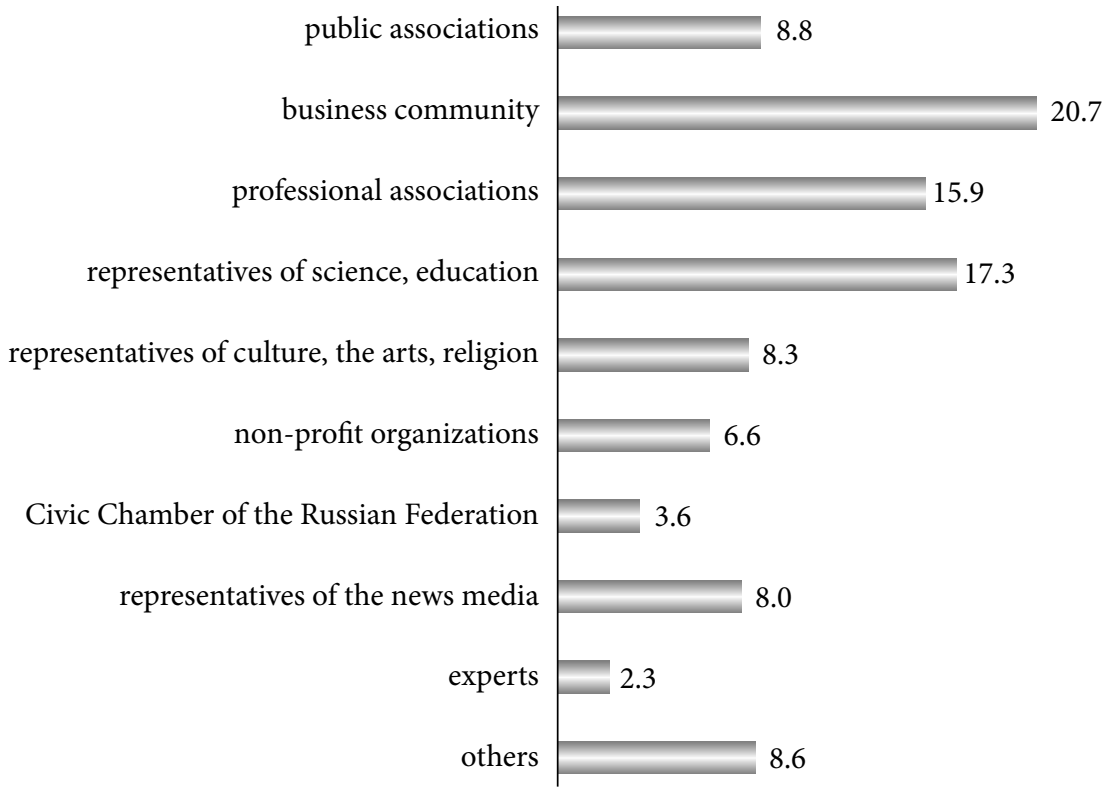

The figure shows the percentage distribution of interest-group representation in the approved memberships of civic councils attached to federal executive agencies. The diagram shows a clear predominance of professional experts on civic councils over representatives of the public.

It is worth noting that, in addition to civic councils, more than 60 experts' councils and the same number of other scientific-technical, coordinating and other councils, commissions and working groups have been established for federal agencies. Many members of civic councils have been included in their memberships as well.

Thus, the system of consultative and advisory bodies at the federal level alone currently numbers about 200 councils (for 78 FEAs) and more than 3,500 participants who have been recruited to serve on them. 
An analysis of the practice of applying the law in involving citizens and public associations in the process of formulating and implementing government policy as part of the activities of civic councils attached to federal executive agencies shows that this work so far has been quite ineffective. For example, in the first nine months of 2014, all operating civic councils attached to federal agencies considered at their meetings a total of 76 drafts of regulatory and legal statutes, one draft per council (with the exception of the civic council attached to the Russian Ministry of Labor, which has considered 22 drafts at seven meetings held in 2014). In the process, Resolution No. 877 of the Russian Federation Government of September 1, 2012, approved the list of regulatory and legal statutes and other instruments drafted by federal agencies that may not be adopted without prior discussion at meetings of their civic councils. We should also underscore the fact that during the same period more than 6,500 drafts and about 700 notifications that must be considered at civic councils were posted at a common portal for posting information on the drafting by federal executive agencies of regulatory and legal statutes.

Civic councils attached to federal agencies were even less productive in considering other matters prescribed in approved statutes. For example, in 2014 only a few civic councils considered at their meetings reports on the work of the agencies for which they were established, in specific areas: under the Russian Health Ministry, the Federal Tariff Agency, Rosfinnadzor (Federal Financial and Budgetary Oversight Agency), and Rosgranitsa (Federal Agency for the Development of State Border Facilities) - an evaluation of the performance of agencies in 2013; under the Ministry of Education and Science - on the results of the implementation of the Ministry's Public Declaration; under the Federal Migration Service on the progress of implementation of the Service's Plan of Activities for 2013-2018; under the Ministry of Internal Affairs - a report on the implementation of the roadmap for reform of the Ministry; under the Ministry of Construction - on the implementation of the government program "Providing Affordable and Comfortable Housing and Utilities for Citizens of the Russian Federation."

The number of other initiatives on the agendas of meetings of the civic councils is either minimal or there are none at all.

We believe one of the reasons for the unsuccessful restart of the civic councils and their ineffectiveness is the unbalanced representation of interest groups on them.

On the one hand, the work to identify interest groups for each agency has only begun and is having significant difficulties: the groups themselves are being structured incorrectly (for example, at a number of agencies one of the groups was defined in formal bureaucratese as "citizens"), and there is no key principle for identifying the interest groups - the powers, goals, or mission of the government agency. On the other hand, the civic councils, which essentially must act as public barometers of the attitudes and expectations of various interest groups, are turning into just another experts' community that advises the agency on matters that are important to bureaucrats but not to citizens.

Over the 30 years in which stakeholder theory has developed, several approaches have evolved in the academic and specialized literature to identifying stakeholders (groups). Within the scope of our study we will highlight only two aspects, which 
are important for understanding the mechanism of identifying interest groups and taking their interests into account in the activities of government bodies.

First, unlike the role of stakeholders in private companies, regarding whom and in whose interests a large portion of the research was conducted, the interest groups of a government agency must not exert direct influence on the decisions it adopts because of the legal status of civil service. Otherwise, given the absence of rules on lobbying in Russian law, such activities may become a corrupting element.

Second, the fundamental way in which the interest groups of a government agency differ from the stakeholders of a private company is that the government agency must take into account the interests of both those who benefit from its decisions and those whose position becomes impaired. Therefore the point of identifying interest groups for a government agency is to determine in each regulated area the range of citizens' social groups for which the decisions or actions of the government agency create, according to Tullock, externalities, both positive and negative, or "activities that harm or benefit someone without his consent" (Tallok, 2011). By relying on a graph of the normal distribution of potential externalities, one can propose a technique for each agency to select and structure its own interest groups.

It is fundamentally important that consideration of the interests of various interest groups becomes an indispensable condition of success for the implementation of large-scale projects of government information systems, as well as the introduction of a system of open government (Bretschneider \& Mergel, 2010; Scholl, 2004).

\section{The first results of the publication of open data}

The use of open government data (the authors regard this term as identical to PSI, except that open data, unlike PSI, are always provided free of charge $)^{1}$ became a priority for federal executive agencies throughout 2013 as a result of the issuance of Decree No. 601 of the President of the Russian Federation dated May 7, 2012, "On the Main Areas for Improvement of the System of Public Governance."

Below are some results of the experts' rating of the work of federal agencies with open data:

- $\quad$ as of October 1, 2014, 1,017 open-data sets had been published at the official websites of 78 federal executive agencies;

- $\quad 71$ federal agencies publish open data in a format no lower than "2 stars";

- 47 agencies post the terms of use of open data, and three of them (the Ministry of Industry and Trade, the Federal Service for Intellectual Property and the Federal Tariff Agency) published data under the Creative Commons open license;

- at two agencies - the Ministry of Internal Affairs and the Ministry of Culture - software applications were created with open data:

- $\quad$ at the Ministry of Internal Affairs - a tool for emergency communications with the closest police department, searching for the current contact information of the local police officer and station address; and a service for online filing of messages to the MIA unit in a specific region;

- at the Ministry of Culture - the Statistics of Cultural Institutions of the Russian Federation contain statistics for all types of cultural institutions in the Russian Federation from 2001 through 2011; 
- the websites of five federal agencies count views and downloads of open-data sets: the Ministry of Labor, the Ministry of Culture, the Ministry of Finance, the Federal Migration Service, and the Federal Tariff Agency. The websites of the Finance Ministry and the Federal Migration Service conduct an overall count for the year, while the others conduct it on a weekly basis. This indicator indirectly shows how much (or little) interest users of the website of a federal executive agency have in the open-data sets that are posted.

Another indicator used by experts is the number of open-data sets that federal agencies publish above and beyond the mandatory list prescribed by Directive No. 1187-r of the Russian Federation Government dated July 10, 2013. Currently there are not many such agencies: the Finance Ministry, the Culture Ministry, the Ministry of Education and Science, the Ministry of Industry and Trade, the Ministry of Internal Affairs, the Roskomnadzor (Federal Service for Supervision of Communications, Information Technology, and Mass Media) and others. The activist agencies boast not only a large number of published open data sets but also a high formatting level of data storage, they have data sets that are potentially valuable for consumers.

As the experts' ratings showed, federal agencies are not only organizing their work with open data. At the current (initial) stage government bodies are publishing open data pursuant to the guidelines of the Ministry of Economic Development, creating certificates for open-data sets and a registry of all open-data sets. We should note the high formatting level at which open data are posted at most federal executive agencies: the dominant formats are XLS and CSV, which make the data machine-readable.

Unfortunately, there are very few "big" data sets that contain both a complex structure and a large number of entries (lines) in the data set. Most open data deal with the agencies' internal operation and contain information that is of little interest to the public at large.

Finally, mention should be made of the successes of the open-data project at the regional level. One example is the portal data.mos.ru, where 260 data sets have been published and mobile apps are successfully functioning, such as:

- "Places for Moms" - allows moms to look on the map for recreational places to go to with their children;

- "Get to Know Moscow" - a guide to interesting places in Moscow;

- "Moscow's Ice-Skating Rinks" - a guide to ice rinks, with an analysis of prices and conveniences;

- "Moscow Parking" - a search for available parking spots in the city and payment for them by cell phone.

At the time of this writing, there were 28 apps at data.mos.ru. The total number of downloads of all data sets since the portal went online in February 2013 has exceeded 770,000.

\section{The presence of federal executive agencies in social networks}

Social networks today are a universally recognized Internet tool for involving citizens in a discussion with government bodies both on private matters and on large-scale, socially important problems. 
As Lazer et al. (2009) note, government bodies can determine through social networks how much support their objectives (mission) have in society. Mergel (2013) proposes a three-stage model of steady development of the presence of government bodies in social networks: from providing information through counseling to joint project work. Criado et al. (2013) show that government bodies use the social networks that are most popular among the public.

According to LiveInternet, as of the end of April 2014 the number of users of Facebook in Russia was 23.8 million, while for the VKontakte network (the Russian counterpart of Facebook) it was 52.1 million. $^{3}$ The developing popularity of foreign and Russian social networks has not gone unnoticed by federal agencies.

In characterizing the presence of federal agencies on social networks as one of the tools of openness, we should note that the extent to which this tool has been implemented at federal executive agencies varies significantly, although on the whole it is still at a fairly low level - based on Mergel (2013), at the level of providing information.

According to the expert rating data, the presence on social networks of federal executive agencies is distributed as follows:

Twitter, 31 FEAs (40\%); Facebook, 26 (33\%); YouTube, 14 (18\%); VKontakte, 13 (17\%); Instagram, 8 (10\%), LiveJournal, 7 (9\%), Odnoklassniki, 2 federal agencies. The leaders among federal agencies are: Rosreestr (Federal Service for State Registration, Cadastre and Cartography), in 8 social networks; the Ministry of Emergency Management and the Federal Antimonopoly Service, in 6; the Ministry of Internal Affairs, the Culture Ministry, and Roskosmos (Federal Space Agency), in 5 social networks.

The experts' ratings have identified some highly successful experience that has been gained by federal executive agencies:

- the Ministry of Foreign Affairs - the level of 397,000 subscribers to Twitter and 155,000 to Facebook is continually maintained by the posting of up-todate news in real time, with a large amount of video and graphics;

- the presence of the Ministry of Emergency Management on VKontakte (more than 28,000 subscribers) features substantive material and current topics, as well as an active response to comments and questions from users; the MEM today has more than 280,000 subscribers on Twitter;

- posts by the Ministry of Defense on social networks (e.g. Facebook) receive strong support from users in the form of "Likes" (there are news items that receive up to 150 Likes);

- the Ministry of Education and Science in 2013 won the Runet Blog Prize in the category of "Blog on Science and Education."

The vast majority of federal agencies, however, have chosen the tactic of a one-way channel of information for citizens, broadcasting news from their official website, including the identical audio and video content, to all social networks on which the agency is present, regardless of the specific type of audience.

Far from every federal agency publishes the rules of operation and conducting a dialog on its page. Examples of the posting of operating rules are presented on the MEM page on VKontakte (http://vk.cm/mchsgov), and the Ministry of Education and Science page on LiveJournal (http://mon-ru.livejournal.com/67185. 
html). Many agencies have not undergone verification by the administration of the social network and have not received a "seal of authenticity."

Yet the strategy of one-way information signifies minimal activism by citizens. They do not consider it necessary or useful to themselves to participate in writing comments or questions on the news posted by agencies on social networks, which is uninteresting, uninformative and do not deal with matters that are relevant to citizens or specific interest groups.

The majority of agencies on social networks do not moderate or provide incentives for debates on socially important problems. Often only posts are published, but a forum debate on the social-network page is not supported. Agencies do not make use of a whole host of opportunities to provide information on the social network in a convenient form, for example, a calendar of events or various information applications (such as links to Twitter and YouTube from other social networks, a video-streaming application, etc.).

One of the reasons, in our view, is that the employees of agencies who are responsible for communicating with the public on social networks often do not have the necessary skills, including setting up forums, publishing operating rules, posting pictures, structuring information on a page, and so forth. Another reason is the absence of internal rules or policies that officials could follow when interacting with interest groups through social networks.

The problem of filling an agency's official page with content on social networks right now is still highly important for federal executive agencies. The more serious the problems to be discussed, the larger the audience and the higher user activity is. Conversely, filling a page in a perfunctory manner on a social network with irrelevant content that does not deal with citizens' real problems is more likely to weaken the government agency's authority among social-network users and not to increase confidence in it.

The most difficult problem is still the conversion of activism on social networks to concrete work by the government agencies (e.g. the initiation of a new project, the drafting of a regulatory or legal statute or guidelines, the revision of industry regulations, etc.). It is impossible to establish a connection between initiatives on social networks (when they are put forth by citizens) and the decisions formulated by agencies. A typical example is the large number of polls on social networks whose results are not implemented as practical projects.

Thus, social networks today are viewed by government agencies primarily as an additional channel for providing information to citizens. And as a consequence, there are very few citizen initiatives and serious debates on the pages of federal agencies on social networks.

\section{Outlook for the development of a system of open government}

The Openness Standards for Federal Executive Agencies in Russia define four principles and 10 mechanisms (tools) of openness. Today the task is, by developing legislation and administrative practice, to expand the basic elements of the system of open government to the regional and municipal levels of governance. 
The development and adaptation of openness tools define the interest groups. Therefore involving regional entities in this process will promote not only the proliferation of the open-government system but also a qualitative improvement of the openness tools themselves and the system of rating and evaluating the openness of federal executive agencies.

A rating of the openness of executive agencies based on a three-tier system of evaluation will make it possible to accomplish several tasks simultaneously:

(1) by comparing the experience of other bodies, federal agencies will be able to adopt the most successful practices;

(2) an opportunity opens up for their regional counterparts to develop similar mechanisms in the provinces;

(3) the country's leaders can use the ratings of the openness of federal agencies to evaluate the effectiveness of interaction with civil-society institutions and the level of public confidence in the heads of federal agencies;

(4) for citizens, taking part in the evaluation is an excellent opportunity to articulate their expectations of the federal government, and the rating results are a way to inform the public about the performance of federal agencies and a good incentive to get involved in the formulation and implementation of government decisions.

Improving legislation in this area remains an important factor, which will predetermine the development of an open-government system in Russia. On the one hand, there is a substantial layer of conflicts in the law that need to be resolved and are preventing the work of executive agencies from being optimized through the introduction of ICT. For example, reducing the costs of processing citizens' communications by building up a social-network presence. On the other hand, the enactment of regulatory and legal statutes must support and expand effective administrative practice in introducing openness principles by formally establishing quantitative and qualitative indicators of the productivity of openness mechanisms.

In the medium term, the technological component of the application of openness tools must grow, since a high growth rate of Internet access for Russians increases their demand for virtual interaction on the whole, including with government agencies.

We will now take a look at the basic prospects for the development of the openness mechanisms described in this paper.

Russia has not yet settled the question of the type of license under which open data are provided. The majority of federal executive agencies (except for three) do not use licenses, replacing them with independently formulated terms of access to open data. In our view, the use of the international Creative Commons license is a step toward unifying the rules of working with governmental open data on an international scale, as well as an opportunity to raise Russia's international rating in the realm of open data.

As part of the experts' rating, we discovered activist agencies that offer industry data that should draw the attention of various interest groups and that require further, serious work in data discovery, including from various internal information systems. We believe there is a potential for expanding the group of activist agencies. Unfortunately, at the federal level the principal beneficiaries of the "open 
data" project to date are still sectoral experts' communities, major news agencies, and independent analysts. But the involvement of new interest groups in this process must grow. Otherwise, work with open data cannot be considered satisfactory.

In our view, the most important area in working with open data at the federal level should be interagency work to create truly valuable data sets, based on data from different information systems operated by various agencies. It is enough to publish 20 valuable data sets to draw an avalanche of interest from designers, experts and journalists in the use of such information. Achieving this goal requires continuing the process of inventorying agency information systems, conducting a dialog with society regarding interest in various data files, organizing interagency work to coordinate data-exchange processes and establish periods of data updating.

It also seems to us that the substantial costs of keeping technically current many data sets that are not in demand is an expensive process that has no value to society.

Requests have been gathered today from a large number of representatives of interest groups to open up complex and useful data sets. ${ }^{4}$ Targeted work should continue to ascertain the demand and needs of the members of key interest groups with regard to the regulation of agencies, providing an incentive for cooperation on the basis of opening up data and solving sectoral problems with innovative methods.

The operating costs of agencies related to meeting requirements for the publication of open data sets should be shouldered by the federal open-data portal data.gov.ru - which was launched at the end of 2013. The portal team should become the key leader in promoting open government data, enlisting a broad audience for cooperation and stimulating and evaluating the demand for open government data.

With regard to developing the system of consultative bodies attached to federal executive agencies, the most pressing task today is still to delineate the functions of civic and experts' councils. Unless experts' and consultative functions are differentiated from public monitoring functions, it is impossible to build an effective and constructive dialog between a government agency on the one hand and interest groups and civil-society entities on the other.

The development of a mechanism of interaction between government agencies and interest groups through social networks in Russia will involve formalizing the internal work rules of civil servants on social networks, which will describe how to provide information while differentiating among the needs of interest groups and how to answer citizens' questions and comments.

The interaction between agencies and citizens on social networks is already today becoming for the agencies a way of analyzing public opinion and testing the extent to which citizens understand and support the agency's goals and tasks. This trend will intensify.

Finally, interaction on social networks may be used by agencies as a platform for testing new ideas and projects, and it is important to stress that this will be done on the agencies' initiative.

Another aspect of the formalization should be to accumulate communications practices on social networks and to analyze the application of the law so as to determine compliance with current laws on access to information, on protecting 
personal data, on the mass media, and so forth. Russia will have to go through a wave of debates about the sufficiency, timeliness, and reliability of the government information that is provided. It is quite possible to create an institution of information ombudsmen, who would uphold citizens' rights to information, and to promote the creation of an objective evaluation of the consequences of providing government information at official websites and on social-network pages.

The development of the system of evaluating the openness of executive agencies will be of particular importance. Evaluation of the performance of government agencies on social networks, in our view, could become one indicator not only of the openness of federal executive agencies, but also a component of the rating of the quality of public governance.

\section{Conclusion}

The results of the experts' rating of the introduction by federal executive agencies of openness mechanisms confirm our hypothesis that there is an internal relationship between the principles and mechanisms of openness and the presence of a multiplier effect when creating open government as a system.

As was shown above, an absence of interest groups that are structured according to the goals (regulatory areas) of a federal agency leads to serious distortions in picking the members of civic councils. A narrow, expert-based civic council, in turn, significantly shrinks the list of matters that are considered at its meetings. A civic-council agenda that is created on the basis of the agency's interests rather than those of representatives of a broad range of interest groups, which is not of interest to citizens, cannot generate an active and serious public debate, including on social networks. Furthermore, a strategy of behavior for a federal executive agency on social networks that is primarily aimed at reporting on decisions that have been adopted provides no incentive for citizens to discuss and propose alternative solutions to various problems of socio-economic development. Ultimately, an unwillingness to implement decisions that have been adopted without considering people's opinions leads to a disregard by them and disrespect for government institutions.

Therefore, despite the fact that the mechanisms (tools) of openness may be regarded as independent phenomena, the effectiveness of their practical implementation in public governance depends on how integrated their development is, since the relationships among them as elements of an open-government system remain highly important, which was demonstrated in our work.

Hence a consistent implementation of an open-government system in the activities of executive agencies at the federal and regional levels makes it possible to advance to a qualitatively different level of public governance.

The primary area for further study of an open-government system must be the improvement of the rating and evaluation of its effectiveness. Another area is the search for new mechanisms and technologies that institutionalize the interaction between government agencies and civil-society entities. In our view, the ratings by experts of the implementation of openness principles and mechanisms could become a source of ideas. 


\section{REFERENCES}

1. Bretschneider, S.I. \& Mergel, I. (2010). “Technology and public management information systems: where we have been and where we are going." In The state of public administration: issues, problems, and challenges, eds. D.C. Menzel \& H.L. White, pp. 187-203. Armonk, NY: M.E. Sharpe.

2. Burkert, H. (2004). The Mechanics of Public Sector Information. In Public sector information in the digital age: between markets, public management, and citizens' rights, eds. G. Aichholzer \& H. Burkert, pp. 3-19. Cheltenham, UK: Edward Elgar.

3. Criado, J., Sandoval-Almazan, R. \& Gil-Garcia, R. (2013). "Government innovation through social media." Government Information Quarterly, vol. 30, n. 4, pp. 319-326.

4. Fountain, J. (2001). Building the virtual state: information technology and institutional change. Washington, DC: Brookings Institution Press.

5. Freeman, R.E. (1984). Strategic management: a stakeholder approach. Boston, MA: Pitman.

6. Goldsmith, S. \& Eggers W. (2004). Governing by network: the new shape of the public sector. Washington, DC: Brookings Institution Press.

7. Janssen, M. \& Estevez, E. (2013). Lean government and platform-based governance: doing more with less. Government Information Quarterly, vol. 30, S1-S8, pp. 51-58.

8. Lazer, D., Pentland, A., Adamic, L., Aral, S., Barabási, A., Brewer, D. \& Van Alstyne, M. (2009). Social science: computational social science. Science, vol. 323, n. 5915, pp. 721-723.

9. Mergel, I., (2013). A framework for interpreting social media interactions in the public sector. Government Information Quarterly, vol. 30, no. 4, pp. 327-334.

10. Mordasova, T.A. (2011). Obshchestvennoe uchastie $v$ politicheskom upravlenii: institutsional'naia sreda i otsenka effektivnosti (Public participation in political governance: institutional environment and performance evaluation). Astrakhan: Astrakhan State University.

11. Organisation for Economic Co-operation and Development, Directorate for Science, Technology and Industry, Working Paper on the Economy. Digital broadband content: public sector information and content (2006). Available: www.oecd. org/dataoecd/10/22/36481524.pdf (accessed: 15 October, 2014).

12. President's Councils (n.d.). Available at: http://state.kremlin.ru/council (accessed: 22 October, 2014).

13. Global Right to Information Rating for Russia. Available at: http://new.rti-rating. org/view_country?country_name=Russia (accessed: 24 April, 2015).

14. Russian Government Coordination and Consultation Boards (n.d.). Available at: http://government.ru/agencies/ (accessed: 22 October, 2014). 
15. Scholl, H.J. (2004). Involving salient stakeholders. Action Research, vol. 2, n. 3, pp. 277-304.

16. Smoleva, S.S. (2008). Obshchestvennoe mnenie v usloviiakh informatsionnoi otkrytosti obshchestva (Public opinion in an open-information society). Moscow: Moscow State Open University (MGOU).

17. Sostav ekspertnogo soveta pri Pravitel'stve Rossiiskoi Federatsii ot 6 avgusta 2012 goda (Composition of the Expert Council of the Government of the Russian Federation on 6 August, 2012). Available at: http://government.ru/info/2458/ (accessed: 21 April, 2015).

18. Standart otkrytosti federalnykh organov ispolnitel'noi vlasti (Openness standards for federal executive agencies). Available at: http://open.gov.ru/events/5508409/ (accessed: 22 October, 2014).

19. Stiglitz, J.E. (2000). The contributions of the economics of information to twentieth century economics. Quarterly Journal of Economics, vol. 115, n. 4, pp. 1441-1478.

20. Tallok [Tullock], G. (2011). Obshchestvennye blaga, pereraspredelenie i poisk renty (Public goods, redistribution and rent-seeking). Moscow: Izdatel'stvo Instituta Gaidara.

\section{NOTES}

1 In a 2008 recommendation, the Organisation for Economic Co-Operation and Development (OECD) Council for Enhanced Access and More Effective Use of Public Sector Information defined PSI as "information, including information products and services, generated, created, collected, processed, preserved, maintained, disseminated, or funded by or for the government or public institutions, taking into account (relevant) legal requirements and restrictions".

2 In Tim Berners-Lee's model for assessing how well developed open data are, "two stars" mean that the open data are structured in tabular form (mostly Excel format); "three stars" appear when the Excel format is converted to a nonproprietary format (CSV in particular); and "four stars" are assigned to a set of data when it is possible to link to it on the basis of a unique identifier (URI).

3 LiveInternet - http://lenta.ru/news/2014/04/23/tns/.

4 Report on the Results of Implementing the Open-Data Model in 2013, HSE National Research University - http://opendata.open.gov.ru/upload/iblock/d3a/d3a1d78c5ca9ebd269d38d9ed35ab9d5.pdf. 